\author{
В.С. Храковский \\ Институт лингвистических исследований РАН \\ (Россия, Санкт-Петербург) \\ khrakovv@gmail.com
}

\title{
ДВЕ ПАРЫ ГЛАГОЛОВ: РАДОВАТЬ (НСВ) И РАДОВАТЬСЯ (НСВ), ОБРАДОВАТЬ (СВ) И ОБРАДОВАТЬСЯ (СВ). СЕМАНТИКА И СИНТАКСИС*
}

В статье на примере двух пар соотносительных эмотивных глаголов несовершенного и совершенного вида (радовать и радоваться, обрадовать и обрадоваться) рассматриваются такие их семантические, синтаксические и деривационные свойства, которые могут оказаться существенными для общей характеристики эмотивных глаголов. Ситуация, обозначаемая непереходными эмотивами, содержит двух участников: экспериенцера, который испытывает данную конкретную эмоцию, и стимул, который, существуя до положительной или отрицательной эмоции у экспериенцера, создает ее. Стимул по своему статусу отличается от других семантических ролей. В этой роли может выступать личный участник, предмет и ситуация, а валентность стимула соответственно может реализоваться с помощью различных формальных средств. К тому же эта роль может выражаться не только в приглагольной актантной позиции, но и в предтексте. Содержательно стимул включает в себя две стандартные роли: причину и условие. Что касается переходных эмотивов, то у них два значения: каузативное и конверсивное. При каузативном значении у них три роли: каузатор, экспериенцер и средство каузации (потенциальный стимул). При конверсивном значении у них те же две роли, что и у непереходного эмотива: стимул и экспериенцер. Соответственно, в этом случае соотносительные непереходный и переходный эмотивы отличаются друг от друга только диатезами. Вопрос о соотношении каузативного и конверсивного значений у переходных эмотивов радовать и обрадовать остается дискуссионным. Известно, что они вошли в язык не раньше XVIII в. При этом первоначально глагол радовать употреблялся только в конверсивном значении, а глагол обрадовать - только в каузативном значении. Особо в статье рассмотрен вопрос об отрицательных конструкциях, образуемых глаголами обрадовать и обрадоваться. Показано, что в одних случаях употребляется обычное контрадикторное отрицание, а в других случаях отрицание маркирует антонимичное значение глагольной лексемы.

Ключевые слова: глагол, каузативное значение, конверсивное значение, несовершенный вид, совершенный вид, семантическая роль, отрицание.

* Я сердечно благодарю Адриана Барентсена и Сергея Юрьевича Дмитренко, которые прочитали текст этой статьи и сделали ряд полезных замечаний. 
В этой небольшой публикации анализируются две пары эмотивных глаголов, входящих в кластер «РАДОСТЬ», которые соотносятся друг с другом лексически и формально. Это пара радовать и радоваться (несовершенный вид, далее - НСВ) и пара обрадовать и обрадоваться (совершенный вид, далее - CВ). Глаголы $p a-$ довать и обрадовать являются формально исходными переходными глаголами, а глаголы радоваться и обрадоваться - формально производными непереходными рефлексивными глаголами, которые образованы от исходных глаголов с помощью потенциально многозначного постфикса -ся. Принятый нами формат описания позволяет достаточно подробно охарактеризовать те особенности семантики и синтаксиса отдельных эмотивных глаголов, которые остаются недостаточно раскрытыми или вообще не упоминаются в обобщающих работах, посвященных эмотивным глаголам, и которые тем не менее могут оказаться существенными для общей характеристики этих глаголов ${ }^{1}$.

Свою работу мы хотим начать с констатации следующего важного обстоятельства. Как было доказано Ю. Д. Апресяном в работе [Апресян 1998], в парах соотносительных переходных и непереходных эмотивных глаголов исходными являются непереходные глаголы, несмотря на то что с формальной точки зрения они являются более сложными, поскольку образуются от переходных глаголов с помощью постфикса -ся. По этой причине прежде всего естественно охарактеризовать особенности семантики и синтаксиса непереходных эмотивных глаголов на примере глаголов радоваться (НСВ) и обрадоваться (CВ).

Непереходные эмотивные глаголы неоднократно служили предметом описания, а их итоговая разноаспектная характеристика представлена в работах [Апресян 2015; Ovsjannikova, Say: в печати]. В соответствии с существующими представлениями ситуация, обозначаемая такими глаголами, содержит двух участников: личного участника, выступающего в роли экспериенцера, испытывающего данную конкретную эмоцию, и участника, выступающего в роли стимула, который, существуя до возникновения соответствующей положительной или отрицательной эмоции у экспериенцера, создает еe [cp.: Croft 1993]. Специфическая особенность непереходных эмотивных глаголов НСВ состоит в том, что они обозначают н а л и ч и е у экспериенцера инициируемого стимулом определенного эмоционального состояния, а специфическая особенность переходных эмотивных глаголов СВ состоит в том, что они обозначают инициируемое стимулом в х о ж д е н и е экспериенцера в определенное эмоциональное состояние ${ }^{2}$.

${ }^{1}$ О причинах, побудивших выбрать именно указанные пары для анализа, мы скажем несколько позже.

${ }^{2}$ Может быть, следует состояние радости более точно характеризовать как «активное состояние», поскольку человек, испытывающий эту эмоцию, не пассивен, а активен в том смысле, что он может демонстрировать внешние проявления своей эмоции, см. примеры (20)-(22) [ср.: Вежбицка 1996]. 
Личный участник, выступающий в роли экспериенцера, занимает в конструкции позицию первого актанта «подлежащего» и представляет собой имя или личное местоимение в им. п. В качестве заместителя участника может выступать обозначение какого-либо его реального или воображаемого органа чувств типа глаз, душа:

(1) Душа радуется, когда открываешь сегодняшнюю костромскую прессу (А. Зябликов) ${ }^{3}$;

(2) - Красота! Утром вышел на балкон - глаз радуется! Горы, скальл... а Енисей (Э. Русаков).

Что касается стимула, то и по своему формальному, и по своему содержательному статусу он заметным образом отличается от других семантических ролей. Так, в этой роли может выступать и личный участник, и предмет, и ситуация, а валентность стимула соответственно может реализоваться с помощью различных формальных средств.

Стандартно и личный участник, выступающий в роли стимула, а также различные предметы и ситуации, выступающие в этой роли, оформляются именем в дат. п. ${ }^{4}$ :

(3) Светлячок так обрадовался гостям, что выставил на стол все, что у него было (Г. Юдин);

(4) Молится. Радуется летнему незаходящуему солниу, радуется зимней ночи незаходящей, радуется грешным и праведным, радуется смерти, когда смерть придет (Е.И. Замятин);

(5) В Втот день Штрум не радовался торжеству своей работь, которую, казалось, загнали навек в ящик его домашнего стола (В. Гроссман);

(6) Экс-чемпион мира по шахматам обрадовался терактам в США (Р. Средиземский).

По нашим наблюдениям, не подкрепленным никакими подсчетами, личный участник в роли стимула относительно редко встречается при глаголе радоваться.

Стимульные ситуации могут выражаться и деепричастным оборотом:

(7) Радовался так, как охотник радуется, победив, скажем, тигра в обстановке, близкой к рукопашной (Э. Лимонов);

(8) Дожив до воли, обрадовался, как амнистированный (Ю. Давыдов).

Стимульные ситуации выражаются также придаточными предложениями, вводимыми союзами что, когда, потому что:

(9) Он радуется тому, что скоро поедет во Франциию (А. Геласимов);

(10) Таня же утверждала, что сын ее радуется, потому что она намла ему правильного отияа (Л. Улицкая);

3 Здесь и далее: примеры со ссылкой в круглых скобках взяты из [НКРЯ].

4 Личный участник - это, можно думать, протагонист стимульной ситуации, вычитываемой из контекста. Так, в примере (3) подразумевается ситуация прихода гостей. 
(11) Сама же ГлюкоZа только обрадовалась, что Савичева ее будет показывать (Комсомольская правда. 29.04.2013);

(12) Последнего я знаю со студенческих лет и очень обрадовался, когда узнал, что он становится музыкальным директором театра (Известия. 05.09.2001).

Особо следует отметить, что стимульные ситуации могут выражаться и придаточными предложениями, вводимыми союзом если, что, насколько я могу судить, ранее не отмечалось:

(13) Впрочем, я первый буду радоваться, если ты окажешься права и в результате нечаянной встречи джентльменов погаснет их нелепая вражда (Р. Штильмарк);

(14) Я смотрю на Ивана Васильевича и, как это ни странно, со всей очевидностью понимаю: он обрадуется, если я уеду (В.Д. Пришвина);

(15) Твой прадед, который пришел в Шали из Дагестана пасти баранов и убирать навоз, наверняка обрадовался бы, если бы смог видеть, каким его потомок стал убежденным чеченцем (Г. Садулаев);

(16) Если бы тебя отец отлупил, ты бы обрадовался? (А. П. Гайдар).

Функцию условного придаточного предложения может выполнять и оборот, вводимый формой императива:

(17) Позвони мне та же Ирина или Нина, или ещуе кто из нашей далекой юности, голоса которой звучат все глуше и глуше, то и я бы обрадовался (Е. Шкловский).

Эти и подобные примеры нуждаются в комментариях. Дело в том, что термин стимул практически равнозначен термину причина, которым некоторые исследователи вообще предпочитают пользоваться [см., например: Апресян 2004: 914]. А в приведенных примерах в соответствии с принятой номенклатурой терминов речь идет о стимуле, который представляет собой не причину, а условие. Однако на самом деле это противоречие только кажущееся, поскольку условие - это та же причина, только существующая не в реальном, а в возможном или в ирреальном мире. Соответственно, можно считать, что термин стимул включает в себя и термин причина, и термин условие в их стандартном употреблении.

Еще одна специфическая особенность стимула, отличающая эту роль от других семантических ролей, заключается в том, что она не обязательно выражается в актантной приглагольной позиции. Стимульная ситуация может выражаться в предтексте. При этом необходимо учитывать, что выражение стимульной ситуации в предтексте наиболее часто встречается при глаголе обрадоваться, что вполне естественно, поскольку при этом глаголе маркируется инициируемое стимулом вхождение экспериенцера в данное эмоциональное состояние.

(18) Иду по коридору, вижу: идет дорогой мне товарищз Синицььн в коричневом костюме, брюки у него расстегнуты. Я обрадовался, кричу: - Товарищ, Синицыьн! (Г. Горин); 
(19) Проведите опрос среди знакомых и приилите мне результатыл. Я обрадуюсь. За самую интересную историю обещаю приз (М. Кирцер).

Хотя сама по себе эмотивная реакция экспериенцера недоступна внешнему наблюдению, она может сопровождаться внешним проявлением эмоции:

(20) Рядом с Шуховым Алешка смотрит на солнце и радуется, ульббка на губы сошла (А. Солженицын).

Особенно характерно речевое проявление эмоции:

(21) -А я за тобой, значит, Лида, буду, - радуется вторая старушка, признавшая, видно, по голосу в пришедшей чуть раньше свою знакомую. - Будь, будь, Зоенька! 一 радуется встрече и Лида (Н. Березовский);

(22) И очень приятно, что вы меня поздравляете, - обрадовалась актриса (Комсомольская правда. 26.02.2013).

Наконец, существенно подчеркнуть, что протагонист стимульной ситуации, планируя эту ситуацию, может создавать ее специально для того, чтобы у экспериенцера возникла соответствующая эмоциональная реакция:

(23) Сегодня скажу Юрке, что все будет тип-топ. То-то обрадуется (В. Аксенов).

Можно думать, что в языковом сознании такая эмоция, как радость, трактуется как агентивно выполнимая. Во всяком случае, свободно допускается сочетаемость имени лица, желающего радоваться, с такими агентивными глаголами, как стаpamься, пытаться. При этом данные глаголы, в свою очередь, сочетаются с инфинитивом глагола радоваться, но не обрадоваться 5 .

(24) Но в принщиие статусу фаворита я старалась радоваться (Советский спорт. 04.09.2011);

(25) Тебе было тесно с нами, ты сирота на земле, бедняжка, ты жила в богатом доме и пыталась радоваться как могла (И. Садур).

Также свободно допускается употребление императива глагола радоваться. В [НКРЯ] зафиксировано 828 вхождений формы радуйся и 373 вхождения формы радуйтесь.

(26) На воле твоя последняя вера терниями заглохнет. Tы радуйся, что ты в тюрьме! Здесь тебе есть время о душе подумать! (А. Солженицын);

(27) Если спаржа в ваших руках сломалась, не переживайте, а радуйтесь - она свежая (Г. Деперинс).

В то же время в [НКРЯ] зафиксировано всего три вхождения формы обрадуйся, два из которых мы приводим, и ни одного вхождения формы обрадуйтесь.

${ }^{5}$ Нельзя исключить того, что выражение стараться радоваться значит 'стараться делать вид, что радуешься'. 
(28) Полюби свое дерьмо, - учат мудрецьь - и обрадуйся жизни (С. Бобровский);

(29) И скажи это честно Богу, и покайся, если нужно, и пожалей, - или обрадуйся (митрополит Антоний Блум).

И при глаголе радоваться, и при глаголе обрадоваться личный участник в роли стимула может обозначаться именем, вводимым предлогом за, а неличный участник может обозначаться именем, вводимым предлогом из-за:

(30) Она старалась радоваться за него, но уже ясно понимала, о чем с ним сейчас можно и о чем бесполезно говорить (Ф. Кнорре);

(31) Я радовалась ему, но как бы он не подумал, что я радуюсь из-за прекрасных вещей, которые он каждый раз привозит (А. Терехов);

(32) Мы все очень обрадовались за Вас, когда узнали, что Вы намерены жениться на графине Румяниеевой (Б. Окуджава);

(33) Я так обрадовалась из-за апельсина, а тыл... (В. Аксенов).

Еще одна важная особенность роли стимула, впервые, если я не ошибаюсь, отмеченная в работе [Апресян 2015], состоит в том, что реально различаются два типа стимулов. В первом случае речь идет о стимулах, которые вызывают эмоциональную реакцию экспериенцера, оказавшись, можно сказать, в его поле зрения:

(34) Он будет радоваться солнечному свету, синему небу, щебету птии и попросту ничегонеделанию (А. Грачев);

(35) В конще концов - вокруг совершенно атеистическая страна, и если однажды среди миллионов атеистов я встречу протестанта, я скорее обрадуюсь этой встрече, все-таки близкая душа (А. Кураев);

(36) Открыв дверь, Соня вовсе не обрадовалась гостю (С. Таранов).

Во втором случае речь идет о стимулах, которые представляют собой информацию, полученную экспериенцером, осознание которой и вызывает соответствующую эмоциональную реакцию:

(37) - Я так сильно обрадовалась, когда Наташа сообщила мне по телефону о том, что у них с Антуаном будет маленький, - взволнованно рассказывает бабушка топ-модели Лариса Гавриловна (А. Инешин);

(38) Узнав от журналистов «КП» о найденной подлодке, Галина Морозова очень обрадовалась (Комсомольская правда. 12.07.2013);

(39) Я честно признаюсь, что журналистка из Москвы. И Оля искренне радуется этому известию (Е. Костикова).

Что касается переходных эмотивных глаголов, то, насколько я могу судить, им внимания уделяется меньше [см., однако: Падучева 2001; 2004; Апресян 2015], но в целом предполагается, что они по семантике принципиально не отличаются от непереходных рефлексивных эмотивных глаголов. Ср.: «Emotive reflexives denote roughly the same propositional content as their transitive counterparts and have the same set of semantic participants, viz. an experiencer and a stimulus») [Ovsjannikova, 
Say: в печати]. Если принять эту точку зрения, то переходные эмотивы отличаются от непереходных иерархией участников ситуации, обозначаемой глаголом: стимул у переходных эмотивов занимает позицию первого актанта - подлежащего, а экспериенцер - позицию второго актанта - прямого дополнения, тогда как у непереходных эмотивов позицию первого актанта занимает экспериенцер, а позицию второго актанта - косвенного дополнения - стимул. Еще одно отличие заключается в следующем. Если в конструкции с непереходным эмотивным глаголом первый личный участник, выступающий в роли экспериенцера, имел стандартное оформление (имя в им. п), а второй участник, выступаюший в роли стимула, имел множественное оформление, то в конструкции с переходным эмотивным глаголом оба участника имеют стандартное оформление: первый участник, выступающий в роли стимула, оформляется как подлежащее, а второй участник, выступающий в роли экспериенцера, - как прямое дополнение. Иными словами, переходный эмотив и соотносительный рефлексивный эмотив отличаются друг от друга только диатезами [Падучева 2001; 2004]. Ср.:

(40а) Мой звонок из Москвы в его родной Красноярск очень обрадовал Дмитрия (Н.К. Архипова);

(40б) Дмитрий очень обрадовался моему звонку из Москвы в его родной Красноярск.

Эта точка зрения кажется привлекательной, однако она не учитывает того обстоятельства, на которое обратил внимание Ю.Д. Апресян в своей относительно давней работе, о которой мы уже упоминали [Апресян 1998: 274-275]. Характеризуя эмотивные глаголы, он пишет следующее: «Как показала Л.Н. Иорданская в своем словарном описании глаголов со значением чувства-состояния $<\ldots>$ некоторые глаголы этого класса, например радовать, могут иметь два разных значения. В одном из них они являются каузативами к глаголам типа радоваться $(\mathrm{OH}$ радует меня этим известием = 'Он каузирует то, что я радуюсь этому известию', т.е. радовать = 'каузировать радоваться'), а в другом — конверсивами (Усneхи молодежи радуют старого гроссмейстера < Старый гроссмейстер радуется успехам молодежи)» ${ }^{6}$ [Там же]. Действительно, при названном первым употреблении переходный эмотив является семантическим каузативом непереходного рефлексивного эмотива и позицию первого актанта у переходного эмотива занимает не участник, выступающий в роли стимула, а личный участник, выступающий в роли агенса, или, может быть, точнее, каузатора. Этот участник, ставя своей целью каузировать у участника, выступающего в роли экспериенцера и занимающего позицию второго актанта, соответствующее эмоциональное состояние, выбирает для достижения своей цели соответствующий способ, или, если угодно,

${ }^{6}$ Собственно говоря, указание Ю.Д. Апресяна о том, что глагол радовать в одном случае является каузативом глагола радоваться, а в другом случае - его конверсивом, и побудило нас вновь обратиться к соотносительному анализу этой пары глаголов, дополнив его анализом пары обрадовать - обрадоваться. 
средство каузации. Это средство одновременно является потенциальным стимулом будущего эмоционального состояния экспериенцера. В примере (41) средством каузации является рассказ каузатора, а в примере (42) средством каузации является приезд каузатора.

(41) Я Яадую метра рассказом о реакции Л. Ю. на возрожденный им фильм «Барыиня и хулиган» (В. Смехов);

(42) Я знал, что обрадую его своим приездом (Р. Нахапетов).

В этих примерах роль средства каузации выполняет имя в твор. п. Вместе с тем средством может быть и деепричастный оборот (см. пример 43), и придаточное предложение, см. пример (44):

(43) Петр Петрович меня обрадовал, сообщив, что мне присвоено звание майоpa (Ч. Абдуллаев);

(44) Не уверена, что обрадую вас тем, о чем собираюсь с вами говорить, но все равно приходите (К. Симонов).

Средством может быть и прямая речь каузатора:

(45) Зато в сентябре 2001 года прямо на разводе офицер строевой части «обрадовал» меня: «Саша, ты уволен» (О. Березовский).

Существенно обратить внимание на то, что средство каузации эмоционального состояния, т. е. его будущий стимул, может подсказать каузатору сам экспериенцер.

(46) Если есть возможность, дай мне хоть маленькую весточку о Марье Франизевне. Тьл меня обрадуешь (А.П. Чехов).

Коль скоро в данном случае ситуация, называемая глаголом, является агентивной, то каузатор может предварительно принять решение об ее осуществлении:

(47) Путин собравшихся решил обрадовать с самого начала: им подписан указ о выделении государственных грантов 11 коллективам (Известия. 24.12.2007).

Агентивность ситуации обеспечивает и возможность употребления повелительного наклонения. В [НКРЯ] зафиксировано 12 вхождений формы радуй, 13 вхождений формы радуйте, 25 вхождений формы обрадуй и 8 вхождений формы обpaдyйme.

(48) Ть живи да радуйся, да других радуй (В. Шукшин);

(49) Живите весело и радуйте тех, кто с Вами общзется (А. А. Реформатский);

(50) Хотите чаю? - Обрадуйте, милуша! Люблю очень, когда вы соловушкой заливаетесь (Б. А. Лавренев);

(51) Завтра утром я еду на Весляну лечить зуб, обрадуй мамищу (С. Довлатов).

Стандартно потенциальный стимул становится реальным, однако в принципе в силу различных обстоятельств он может остаться потенциальным. 
(52) Филипп выбежал из храма, хотел обрадовать княгиню неожиданным известием, но она обморочная не внимала ему (Л. Васильева).

Особых комментариев заслуживают примеры типа:

(53) Он радовал меня своей распорядительностью и своим уменьем решать воnросы (Н. С. Хрущев);

(54) Но 5 июня (дата у меня записана) она обрадовала меня своим спокойным видом (Э. Герштейн).

Как и во всех уже рассмотренных примерах, здесь три участника ситуации, но только один участник сохраняет свою роль экспериенцера. Остальные два участника выступают в других ролях. Личный участник - это неагентивный субъект, а неличный - это некоторое свойство этого субъекта, и комплексно они выступают в роли стимула. Фактически такие примеры составляют базу для перехода от каузативного употребления к конверсивному употреблению или, если угодно, к конверсивному значению. Совершенно естественно пример (53) абсолютно синонимичен примеру (55), а пример (54) — примеру (56), который представляет собой конверсивное употребление переходного эмотива.

Меня радовали его распорядительность и его уменье решать вопросы.

Но 5 июня (дата у меня записана) меня обрадовал ее спокойный вид.

Итак, если при каузативном употреблении переходного эмотива ситуация, называемая глаголом, включает трех участников — каузатора, средство каузации эмоционального состояния (иначе - потенциальный стимул каузируемого эмоционального состояния) и экспериенцера, - то при конверсивном употреблении переходного эмотива ситуация, называемая глаголом, включает только двух участников, а именно стимул и экспериенцера, и только в этом случае непереходный и соотносительный переходный эмотивы отличаются друг от друга диатезами. В диатезе непереходного эмотива первый участник - экспериенцер - занимает позицию подлежащего, а второй участник - стимул - занимает позицию косвенного дополнения; а в диатезе переходного эмотива первый участник - стимул занимает позицию подлежащего, а второй участник - экспериенцер - занимает позицию прямого дополнения: диатеза непереходного эмотива является исходной, а диатеза переходного эмотива — производной. Ср. (55) и (56), (57) и (58):

Я радовался его распорядительности и его уменью решать вопросы.

Но 5 июня (дата у меня записана) я обрадовалась ее спокойному виду.

Заслуживает внимания вопрос об оформлении участников ситуации в диатезе переходного эмотива при его конверсивном употреблении. В целом стандартным является оформление участника ситуации, выступающего в роли экспериенцера. Этот участник занимает позицию прямого дополнения и оформляется вин. п. Важно обратить внимание, что, как и при непереходном эмотиве, в роли этого участника может выступать в качестве заместителя участника обозначение какого-либо его реального или воображаемого органа чувств типа глаз, душа. 
(59) Только краеведческий музей радует глаз (В. Лейбин, Г. Тарасевич);

(60) Пустынный пейзаж не радовал глаз, и отчаяние охватывало первых поселенцев (С. Аксентьев).

Сложнее обстоит дело с оформлением участника, выступающего в роли стимула, который занимает позицию первого актанта - подлежащего. С самого начала отметим, что у переходного эмотива нет диатезы, которая бы соответствовала такому употреблению непереходного эмотива, когда стимул выражается не в приглагольной позиции, а в предтексте, см. примеры (18)-(19). У переходного эмотива все участники ситуации занимают приглагольные позиции. Важно обратить внимание на следующее обстоятельство. У непереходного эмотива позицию первого актанта стандартно занимает личный участник, который, если не учитывать слово дитя, всегда является словом мужского или женского рода, и это слово согласуется с формой того же рода глагола прошедшего времени. Что касается переходного эмотива, то при нем позицию первого актанта занимает слово, выступающее в роли стимула, которое вполне может быть именем или местоимением среднего рода, соответственно, согласующееся с формой глагола прошедшего времени среднего рода.

(61) После продолжительного «царства женщчин» появление на троне императора радовало не одних гвардейцев (И. Андреев);

(62) П Пкковичи как жители большого города у Арсения тоже ничего не спрашивали, и Арсения это радовало (Е. Водолазкин);

(63) В Гибралтаре всех обрадовало солнще, было похоже на раннюю весну (И. А. Бунин);

(64) Приветствие это ничуть не обрадовало Никанора Ивановича (М. А. Булгаков).

Обратим внимание на то, что именно такая форма глагола, как и форма глагола 3 л. ед. ч., употребляется, если стимул представляет собой придаточное предложение.

(65) Особенно меня радует, что на концертах фестиваля бывает много детей (И.К. Архипова);

(66) Меня радует то, что труды мои и пролитая кровь не пропали даром (А. А. Авдеев);

(67) Меня, естественно, обрадовало, что все магазины здесь открыты престижными фирмами зарубежных держав (С. Есин).

Специально отметим, что в этой роли может выступать и личный участник, который не является в данном случае каузатором:

(68) Сергей Льнявин за судьбами своих подопечных, окончивиих обучение, старается следить. Кто-то радует, кто-то не очень (А. Бернашвили);

(69) Молодец Кузнецова, ты меня искренне радуешь (В. П. Катаев).

Обычны в этой роли предметные имена и имена, обозначающие ситуации, а также заменяющие их местоимения: 
(70) В остальном встречный экскаватор не радовал глаз (С. Носов);

(69) В итальянском обувном магазине терпко пахло хорошо выделанной кожей. Марию радовал этот запах (В. Михальский);

(71) Возня с детворой ее больше не радовала (И. Грекова);

(72) И наконеи, нас радует это, как радует всякая история любви (Ю. Пешкова).

Что касается сущностных различный конверсивного и каузативного употребления переходного эмотива, то они могут быть сформулированы следующим образом. При конверсивном употреблении переходного эмотива и соотносительном употреблении непереходного эмотива экспериенцер приходит в соответствующее эмоциональное состояние благодаря наличию стимула.

При каузативном употреблении переходного эмотива каузатор целенаправленно вызывает у экспериенцера соответствующее эмоциональное состояние, называемое непереходным эмотивом, с помощью специального средства, которое становится стимулом этого эмоционального состояния.

Естественно возникает вопрос о соотношении конверсивного и каузативного употреблений переходных глаголов. Данными об употреблении переходных эмотивов до XVIII в. мы не располагаем. Похоже, что переходные глаголы радовать и обрадовать вошли в употребление не раньше XVIII в., а XVIII в. демонстрирует противоречивую картину. Согласно [НКРЯ], глагол радовать в это время употребляется только в конверсивном значении ${ }^{7}, \mathrm{cp}$.:

(73) Мысль, что каждую минуту приближаюсь к отечеству, живит и радует мое сердие (Н. М. Карамзин);

(74) Меня очень радует, что юношество делает успехи в гимназии и кое-чем выделяется, желаю дальнейших успехов (В.Н. Татищев).

Что касается глагола обрадовать, то он, напротив, употребляется только в каузативном значении:

- Хорошо, - отвечал я, - поди и сторгуй сажен с тридиать. Но слуга вскоре обрадовал меня ответом, что сажень с перевозом продается по рублю (Н.И. Новиков);

(76) На другой день, поутру, еще не успело рассвенуть, любовник мой пожаловал ко мне для посещения; он меня чрезвычайно обрадовал, сказав, что отеи его совсем выздоровел и что мы очень скоро опять отправимся в город (М.Д. Чулков).

Такое распределение употреблений требует объяснения, которого у меня пока нет. Могу лишь предположить, что оно связано с видовой спецификой глаголов. $\mathrm{HCB}$, как известно, маркирует отсутствие изменения ситуации. При конверсивности изменения ситуации практически не происходит. По этой причине в своих первых употреблениях глагол радовать выступает в конверсивном значении. СВ,

7 Указанием на наличие подобных примеров я обязан А.В. Птенцовой. 
напротив, маркирует изменение ситуации, и, соответственно, глагол обрадовать в своих первых употреблениях выступает в каузативном значении.

Если до сих пор мы рассматривали проблемы, общие для всех эмотивных глаголов, то теперь мы кратко охарактеризуем семантические особенности отрицательных конструкций, образуемых глаголами обрадоваться и обрадовать. Дело в том, что наряду со стандартными употреблениями таких конструкций, в которых обозначается то, что экспериенцер не входит в позитивное эмоциональное состояние, имеются и нестандартные употребления таких конструкций, в которых обозначается, что экспериенцер входит в противоположное - негативное - эмоциональное состояние типа огорчиться, причем такая интерпретация обычно имеет и соответствующую контекстную поддержку. Иначе говоря, в первом случае употребляется обычное контрадикторное отрицание, а во втором случае отрицание маркирует антонимичное значение глагольной лексемы.

Что касается глагола обрадоваться, то у его форм прошедшего времени муж. р. ед. ч. (125 вхождений в [НКРЯ]), жен. р. ед. ч. (58 вхождений в [НКРЯ]) и мн. ч. (21 вхождение в [НКРЯ]) как будто бы без заметного предпочтения есть употребления обоих типов. Стандартное употребление демонстрируют следующие примеры:

(77) Игорь Борисович не удивился и не рассердился, но и не обрадовался (В. Крапивин);

(78) И потом, когда укол сделали, он не обрадовался, хотя весь класс ему теперь завидовал (Ф. Искандер).

Нестандартное употребление представлено в следующих примерах:

(79) Увидев милицию у ворот, я, естественно, не обрадовался (Д. Коралис);

(80) - Ну ладно, может, Индия - это и не так плохо, - неожиданно перерешила Нюрка, но таким тоном, что я не обрадовался (Г. Прашкевич, Н. Богдан).

Иначе обстоит дело с формами будущего времени 3 л. ед. ч. (32 вхождения в [НКРЯ]) и мн. ч. (5 вхождений в [НКРЯ]). На наш взгляд, стандартное употребление этих форм 3 л. встречается относительно редко.

(81) Может, он мне вовсе и не обрадуется (М. Петросян).

Нестандартное употребление этих форм 3 л. встречается чаще, и оно является типичным для форм 2 л. ед. ч. (42 вхождения в [НКРЯ]) и мн. ч. (9 вхождений в [НКРЯ] $)^{8}$.

(82) Твоя мама точно не обрадуется, если в придачу к папиному аресту получит и тебя на больничной койке. - Не обрадуется, - пришлось согласиться мне (Т. Сахарова);

(83) - - Hy, mеперь этот гад у нас не обрадуется (В. Пьецух);

\footnotetext{
${ }^{8}$ Форм 1 л. в стандартном и нестандартном употреблении в [НКРЯ] не зафиксировано.
} 
(84) Молчи, они сейчас булочника позовут и такое обвинение на тебя состряпают, что не обрадуешься (О.Д. Форш);

(85) Подожди, я вам тут шорох наведу - не обрадуетесь (Д. Коралис).

У форм прошедшего времени муж. р. ед. ч. (22 вхождения в [НКРЯ]), жен. р. ед. ч. (25 вхождений в [НКРЯ]) и мн. ч. (9 вхождений в [НКРЯ]) глагола обрадовать также есть как стандартные, так и нестандартные употребления. При этом, на наш взгляд, вряд ли можно говорить о заметном предпочтении тех или других употреблений. В следующих примерах приводятся стандартные употребления:

(86) Непонятно было только, почему не обрадовала эта наконец обретенная свобода от прошлого (А. Берсенева);

(87) Его не удивила и не обрадовала победа над акулами (С. Жемайтис).

Нестандартное употребление демонстрируют следующие примеры:

(88) Когда пришла призывная пора, меня этот факт не обрадовал (О. Фукс);

(89) Известие о том, что у него есть жена, совсем ее не обрадовало (А. Берсенева).

Что касается форм будущего времени глагола обрадовать, то ситуация, на наш взгляд, выглядит следующим образом. У форм 3 л. ед. ч. (17 вхождений в [НКРЯ]) и мн. ч. (3 вхождения в [НКРЯ]) без каких-либо предпочтений есть как стандартные, так и нестандартные употребления. В следующем примере представлено стандартное употребление:

(90) И даже если книжка будет куплена, это его не обрадует (К. Крылов).

Ниже приводится пример нестандартного употребления:

(91) — Есть новости? - Eсть, но они вас не обрадуют. Объявился подозреваемыцй (Т. Сахарова).

В [НКРЯ] есть всего четыре вхождения форм 2 л. ед. ч. и одно вхождение формы мн. ч., в которых представлено стандартное употребление. Вот один из таких примеров:

— Почему не обрадуешь стариков и не вернешься домой? (С. Романов).

Также в [НКРЯ] представлено всего четыре вхождения форм 1 л. ед. ч. и одно вхождение формы 1 л. мн. ч., в которых представлено нестандартное употребление. Приводим один такой пример:

(93) В то же время не обрадую и тех, кого полностью устраивает статус-кво (Д. Медведев).

Отсутствие у экспериенцера позитивного эмоционального состояния, а не вхождение в негативное эмоциональное состояние, насколько мы можем судить, стандартно обозначается в вопросительной отрицательной конструкции:

(94) Послушай, Буратино, а вдруг она не обрадуется? (А.Н. Толстой). 
Наше итоговое заключение минимально. При детальном исследовании семантики, синтаксиса и деривационной специфики всего двух пар эмотивных глаголов получены результаты, которые, по нашему мнению, в определенной степени существенны для всего класса эмотивных глаголов, а также для теории семантических ролей.

\section{Литература}

Апресян В.Ю. Валентность стимула у русских глаголов со значением эмоций: связь семантики и синтаксиса // Русский язык в научном освещении. 2015. № 1 . C. 28-66.

Апресян Ю.Д. Каузативы или конверсивы? // Типология. Грамматика. Семантика : сб. ст. к 65-летию В.С. Храковского / ред. Н. А. Козинцева, А. К. Оглоблин. СПб. : Наука, 1998. С. 273-281.

Апресян Ю.Д. Радоваться // Апресян Ю.Д., Апресян В. Ю., Бабаева Е.Э., Богуславская О. Ю., Галактионова И. В., Гловинская М. Я., Иомдин Б. Л., Крылова Т.В., Левонтина И.Б., Птениова А.В., Санников А.В., Урысон Е.В. Новый объяснительный словарь синонимов русского языка / под общ. рук. акад. Ю. Д. Апресяна. 2-е изд., испр. и доп. М. ; Вена : Языки славянской культуры, 2004. С. 914.

Вежбиика А. Русский язык // Вежбиика А. Язык. Культура. Познание. М. : Русские словари, 1996. С. 33-88.

HКРЯ - Национальный корпус русского языка [Электронный ресурс]. URL: $\mathrm{http} / / /$ ruscorpora.ru

Падучева E.B. Каузативный глагол и декаузатив в русском языке // Русский язык в научном освещении. 2001. № 1. С. 52-79.

Падучева E. B. Роли участников и диатезы глаголов эмоции // Типологические обоснования в грамматике : сб. ст. к 70-летию проф. В.С. Храковского / отв. ред. А. П. Володин. М. : Знак, 2004. С. 379-389.

Croft $W$. Case Marking and the Semantics of Mental Verbs // Semantics and the Lexicon / ed. by J. Pustejovsky. Dordrecht : Kluwer, 1993. P. 55-72.

Ovsjannikova M., Say S. The Instrumental Case in the Diachrony of Russian Reflexive Verbs of Emotion: From Cause to Content. В печати. 


\author{
V.S. Xrakovskij \\ Institute for Linguistic Studies of the Russian Academy of Sciences \\ (Russia, St Petersburg) \\ khrakovv@gmail.com
}

\title{
TWO VERB PAIRS: RADOVAT' 'MAKE HAPPY' (IPFV) AND RADOVAT'S'A 'BE HAPPY' (IPFV), OBRADOVAT' 'MAKE HAPPY' (PFV) \\ AND OBRADOVAT'S'A 'GET HAPPY' (PFV). THEIR MEANINGS AND SYNTAX
}

Based on two pairs of correlative emotive Russian verbs (radovat' 'make happy' and radovat's'a 'be happy' vs. obradovat' 'make happy' and obradovat's'a 'get happy'), the paper looks into their semantic, syntactic, and derivational properties. Intransitive emotive situations include two participants: the experiencer of the specific emotion, and the stimulus producing the experiencer's corresponding positive/negative emotion. The semantic role of a stimulus differs from all other semantic roles in both formal and substantive status. It can be performed by either a personal participant or an object/situation, with the stimulus's valency marked by various corresponding formal devices. Notably, this role can be expressed not only in an adverbial argument position, but in the preceding text as well. The meaning of stimulus includes two standard roles: cause and condition. Transitive emotives can have two (causative or conversive) meanings. With a causative meaning, they can show three roles: causer, experiencer, or causation instrument (a potential stimulus). With a conversive meaning, they show the same two roles as intransitive emotives. Thus, in this case correlative intransitive and transitive emotives only differ in their diatheses. The issue of the correlation between the causative and the conversive meanings of the transitive emotives radovat' and obradovat' is still unresolved. They are known to have appeared in Russian not earlier than in the $18^{\text {th }} \mathrm{c}$. Initially, radovat' was only used in its conversive meaning, and obradovat', in its causative meaning. The paper makes a special focus on negated constructions with the verbs obradovat' and obradovat's'a.

Key words: verb, causative meaning, conversive meaning, imperfective aspect, perfective aspect, semantic role, negation.

\section{References}

Apresyan V.Yu. [Stimulus Valency in Russian Emotive Verbs: Meaning vs. Syntax Relations]. Russkii yazyk v nauchnom osveshchenii, 2015. No. 1, pp. 28-66. (In Russ.)

Apresyan Yu.D. [Causatives or Conversives?]. Tipologiya. Grammatika. Semantika: sb. st. k 65-letiyu V.S. Khrakovskogo [Typology. Grammar. Semantics: A Collection of Articles for the $65^{\text {th }}$ Anniversary of V.S. Khrakovsky]. N. A. Kozintseva, A. K. Ogloblin (Eds.). St Petersburg, Nauka Publ., 1998, pp. 273-281. (In Russ.)

Apresyan Yu.D. [Radovat's'a 'To Be Happy']. Apresyan Yu.D., Apresyan V.Yu., Babaeva E. E., Boguslavskaya O.Yu., Galaktionova I. V., Glovinskaya M.Ya., Iomdin B. L., 
Krylova T.V., Levontina I.B., Ptentsova A.V., Sannikov A.V., Uryson E. V. Novyi ob"yasnitel'nyi slovar' sinonimov russkogo yazyka [The New Explanatory Dictionary of Russian Synonyms] (2 ${ }^{\text {nd }}$ Ed.). Yu.D. Apresyan (Ed.). Moscow, Vienna, Yazyki slavyanskoi kul'tury Publ., 2004, p. 914. (In Russ.)

Croft W. Case Marking and the Semantics of Mental Verbs. Semantics and the Lexicon. J. Pustejovsky (Ed.). Dordrecht, Kluwer Publ., 1993, pp. 55-72.

Natsional'nyi korpus russkogo yazyka [The National Corpus of the Russian Language]. Available at: http://ruscorpora.ru (accessed 14.10.2019)

Ovsjannikova M., Say S. The Instrumental Case in the Diachrony of Russian Reflexive Verbs of Emotion: From Cause to Content. In print.

Paducheva E. V. [Causatives and Decausatives in the Russian Language]. Russkii ya$z y k v$ nauchnom osveshchenii, 2001, No. 1, pp. 52-79. (In Russ.)

Paducheva E.V. [Participant Roles and Diatheses of the Emotive Verbs]. Tipologicheskie obosnovaniya v grammatike: sb. st. $k$ 70-letiyu prof. V. S. Khrakovskogo [Typological Justifications in Grammar: A Collection of Articles for the $70^{\text {th }}$ Anniversary of prof. V.S. Khrakovsky]. A. P. Volodin (Ed.). Moscow, Znak Publ., 2004, pp. 379-389. (In Russ.)

Wierzbicka A. [The Russian Language]. Wierzbicka A. Yazyk. Kul'tura. Poznanie [Language. Culture. Knowledge]. Moscow, Russkie slovari Publ., 1996, pp. 33-88. (In Russ.) 